an exceptionally distinguished student at King's College, London; and after a period on the staff of the Geography Department there, he became a lecturer in geography under Prof. A. G. Ogilvie at the University of Edinburgh. His published researches into the relations between land forms and river drainage brought him (jointly with his collaborator, Prof. S. W. Wooldridge) the Murchison Grant of the Royal Geographical Society ; and besides other work on geomorphology he has published studies in historical, general and economic geography. His teaching experience is also wide. Before the War he was secretary to the Geography Section of the British Association, and on the Council of the Institute of British Geographers and that of the Royal Scottish Geographical Society. His service with the R.A.F.V.R., in which he won successive promotion to squadron-leader, has been in photographic intelligence, in which he is in charge of a H.Q. Department.

\section{Fellowships for Scientific Research in India}

I.C.I. (India) have offered to the National Institute of Sciences of India the sum of 336,000 rupees (about $£ 25,000$ ) for research fellowships in chemistry, physics and biology, to be held at Indian universities or institutions approved by the Council of the National Institute of Sciences, over a period of five to seven years. Each fellowship will be worth 400 rupees per month and will be tenable in the first instance for two years. There is provision for four new fellowships every year during the period 1945-49. In addition, there will be a grant for research expenses to be made to the fellowship holders according to their needs of special apparatus and materials. For this purpose the National Institute has at its disposal an average of 600 rupees per annum for each fellowship. There will be a grant of 13,200 rupees per annum to the National Institute for five years to enable it to pay for administration and the travelling expenses of such fellows of the Institute as may be selected to visit the fellowship holders at their universities or institutions. Appointment to, and control of, the fellowships will be in the hands of the Council of the National Institute, acting on the advice of a special research fellowships committee, representative of various scientific fields and drawn from various parts of India, so as to include any community, the overriding consideration for membership being scientific fitness therefor. The fellowships will be open to persons, irrespective of sex, race or religion, resident or domiciled in India (British India or the States) and less than thirty-five years of age, and will be tenable at any university or institution in India approved by the Council of the National Institute. Fellows will be permitted to do a limited amount of approved teaching or demonstrating.

The aim of the fellowships is to strengthen research in Indian universities and institutions, and it is hoped that the National Institute of Sciences will spread the research fellowships over them in accordance with this aim, but with the overriding consideration of the scientific suitability of the particular university or institution. As Lord McGowan points out in his letter conveying the offer to the president of the National Institute, these fellowships should do something to encourage the advance of science in India and with it the general prosperity of the country; further, they should assist the National Institute in maintaining its position as the premier scientific body of India. The offer is in many ways parallel with that made to British universities a short time ago by
Imperial Chemical Industries, Ltd., and, it may be presumed, is inspired by the suggestions made by Prof. A. V. Hill in his recent report on research in India (see Nature, May 5, p. 532).

\section{Education in H.M. Forces}

AN encouraging feature in the latest report of the Central Advisory Council for Education in H.M. Forces (October 1944--March 1945) is the considerable increase in the number of organized classes as opposed to single lectures conducted in Service units (see Nature, 155, 611 ; 1945). The latter have decreased by some 19 per cent, while the former show the significant rise of 37 per cent. Outside units, the number of intensive schools and conferences also shows a remarkable increase, and it is particularly gratifying that a growing proportion of these schools and conferences are being conducted on a residential basis. It is distressing, therefore, to find that while there is every indication that the demand for intensive courses will increase, there is little likelihood of the demand being met in full unless residential accommodation is made much more freely available. Four university institutions have already lent hostels for whole-time use for regional committee courses, but more help is urgently needed from Service authorities towards the initial cost of reconditioning buildings and also in facilitating the release of suitable premises.

Although the number of occasional lectures in science shows the same downward trend as single lectures in other subjects, the rapid increase in the number of science classes in units is a useful indication of the way in which Service men and women are pursuing their studies with more serious intent ; it is noteworthy that there has been a big shift from 'non-vocational' to 'vocational' science. Several background courses in science, lasting a week or a fortnight, have also been held, usually at university centres. One regional committee broke new ground by instituting experimental courses on British industries. The object was to provide unit instructors with background information about the actual structure of some of Britain's major industries and then to discuss some of the problems that the industries would have to face in the future. Lectures were given by specialists on various aspects of the industries considered, while visual and other mechanical aids were used to supplement the teaching and discussion. Visits to works and firms also served to provide the necessary balance between detailed knowledge and general understanding of the broad issues affecting each industry. Other useful work carried out by the Central Advisory Council during the halfyear covered by the report was that for soldiers and auxiliaries in hospitals and convalescent homes.

\section{Argentine-British Medical Centre, Buenos Aires}

AN Argentine-British Medical Centre has been established in Buenos Aires, with the assistance of the British Council, to promote closer relations and to facilitate the exchange of information between the British and Argentine medical professions. The Centre has a Committee of Honour, the twenty-two Argentinian members of which include Prof. José Arce, Prof. Pedro Escudero, Prof. B. A. Houssay and Prof. Alfredo Sordelli. British representatives of various branches of medicine have been invited to join this Committee. On the Executive Committee are the president of the Centre (Prof. Dr. Mariano R. 